\title{
Model Matematika Strategi Konservasi Populasi Penyu
}

\author{
Muhammad Wakhid Musthofa \\ Program Studi Matematika, Fakultas Sains dan Teknologi, UIN Sunan Kalijaga, Jl. Marsda Adisucipto \\ No. 1 Yogyakarta, Indonesia
}

Korespondensi; Email: mwakhid_m@yahoo.com

\begin{abstract}
Abstrak
Dalam tulisan ini dibahas kajian model matematika pada kasus penurunan populasi penyu di perairan Canada dan Amerika Utara yang disebabkan oleh perburuan yang terlampau besar dalam rangka memenuhi permintaan perdagangan internasional. Kajian model dimulai dengan mengkaji data penurunan populasi dan membentuk model matematika yang menggambarkan data. Validasi model dilakukan untuk meneliti kesesuaian model dalam menggambarkan keadaan yang sebenarnya. Selanjutnya dirumuskan model matematika dalam rangka menawarkan strategi konservasi populasi penyu.
\end{abstract}

Kata Kunci: Model matematika; Konservasi penyu

\begin{abstract}
In this paper discussed on a case study of mathematical models decline in turtle populations in the waters of Canada and North America due to hunting is too large in order to meet the demand of international trade. Study examined data models starting with declining populations and establish a mathematical model that describes the data. Model validation was conducted to investigate the suitability of the model in describing the real situation. Then formulated a mathematical model in order to offer a strategy of conservation of turtle populations.
\end{abstract}

Keywords: Mathematical models; Turtle conservation

\section{Pendahuluan}

Sea Turtle atau dalam Bahasa Indonesia biasa disebut penyu adalah binatang yang sudah ada sejak ratusan tahun yang lalu dan dapat digolongkan dalam kelompok binatang purba. Sesuatu yang membuat menarik dalam membicarakan populasi ini adalah penurunan populasinya yang begitu tajam hingga mencapai 75\% dalam 15 tahun (antara tahun 1980-1995).

Sejak ketika masih berupa telur, banyak faktor yang mempengaruhi berkurangnya populasi penyu. Beberapa diantara faktor yang dominan adalah pencurian telur oleh manusia, predator telur penyu seperti skunk, coatis, genet cat, dan semut, kerusakan telur karena terendam air laut ketika terjadi gelombang pasang, dan lain-lain. Sesaat setelah menetas dari telur, penyu dengan segera berjalan menuju pantai dan menghabiskan waktunya di lautan. Perjalanan anak penyu dari tempat penetasannya hingga ke laut juga banyak mengalami hambatan. Faktor yang paling dominan adalah adanya para predator anak penyu seperti ghost crab, feral dog (anjing buas), vulture (burung hering), raccon (musang liar), lizard, otter, aligator dan lain-lain (Spotila, 2004, Lutz et al., 2002).

Penyu biasa memakan beberapa tanaman dan hewan lunak, diantaranya adalah rumput- rumputan laut, cray fish, carrion, serangga laut, ikan kecil, dan organisme kecil laut lainnya.

Dikarenakan makanan tersebut hanya terdapat di tempat-tempat tertentu, maka hal ini mengakibatkan adanya persaingan antar penyu dalam mendapatkan makanan (Spotila, 2004).

Rata-rata hidup penyu 40 tahun. Penyu mulai bertelur rata-rata ketika berusia 12 tahun, dengan rata-rata usia subur 18 tahun. Setiap tahun rata-rata penyu bertelur sebanyak 6 kali dengan rata-rata telur yang dihasilkan adalah 81,5 butir. Dari jumlah ini rata-rata hanya 11 ekor saja yang menetas hingga sampai ke lautan dengan harapan hidup (hingga dewasa) 17.5\%. Sekitar 2 sampai 3 tahun 
(rata-rata 2.5 tahun) berturut turut penyu bertelur dan setelah itu 1 sampai 2 tahun berturut-turut tidak bertelur (Spotila 2004).

Ditinjau dari pembagian umur, populasi penyu dapat dibagai menjadi sub populasi sebagai berikut (Spotila 2004, Ripple 1996):

Tabel 1 Pembagian sub populasi penyu.

\begin{tabular}{lr}
\hline Sub Populasi & Umur \\
\hline Hatcling & $0-1$ tahun \\
Small Juvenile & $2-8$ tahun \\
Large Juvenile & $9-15$ tahun \\
Sub Adult & $16-21$ tahun \\
Adult & lebih dari 21 tahun \\
\hline
\end{tabular}

Permasalahan utama yang terjadi pada populasi penyu adalah penurunan populasinya yang begitu drastis dikarenakan campur tangan manusia. Beberapa diantaranya adalah pencurian telur kura-kura, perburuan, dan perdangan ilegal. Grafik berikut menggambarkan tajamnya penurunan populasi penyu akibat campur tangan manusia (Bjorndal 2003, CSTC 1990).

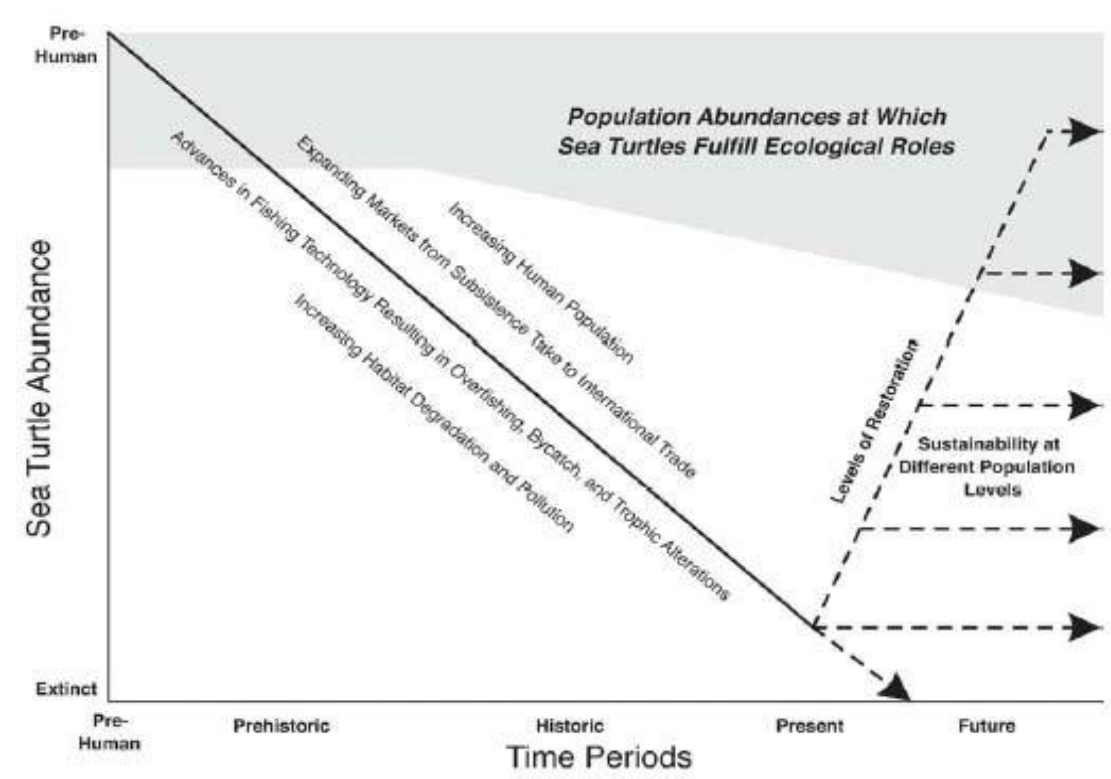

Gambar 1 Penurunan populasi penyu dari masa ke masa.

\section{Latar Belakang Masalah}

Fokus perhatian makalah ini terletak pada penurunan populasi penyu disekitar perairan Canada dan Amerika Utara. Pada tahun 1982 Pritchard (1982) mengestimasikan jumlah populasi penyu di wilayah tersebut sekitar 115.000 ekor. Kemudian pada tahun 1995 diperkirakan polupasinya menurun hingga sekitar 34.500 ekor dan pada tahun 2000 populasinya diperkirakan sejumlah 29.500 ekor. Data populasi dalam 3 selang waktu tersebut dapat disajikan dalam tabel sebagai berikut (Pritchard 1982).

Tabel 2 Data populasi penyu.

\begin{tabular}{cr}
\hline Tahun & Populasi \\
\hline 1980 & 115.000 \\
1995 & 34.500 \\
2000 & 29.500 \\
\hline
\end{tabular}


Salah satu faktor utama penyebab penurunan populasi penyu di wilayah tersebut adalah adanya perburuan yang terlampau besar untuk memenuhi permintaan perdagangan internasional penyu. Data perburuan penyu di wilayah perairan tersebut dari tahun ke tahun disajikan dalam grafik berikut (CSTC 1990).

Tabel 3 Data perburuan penyu.

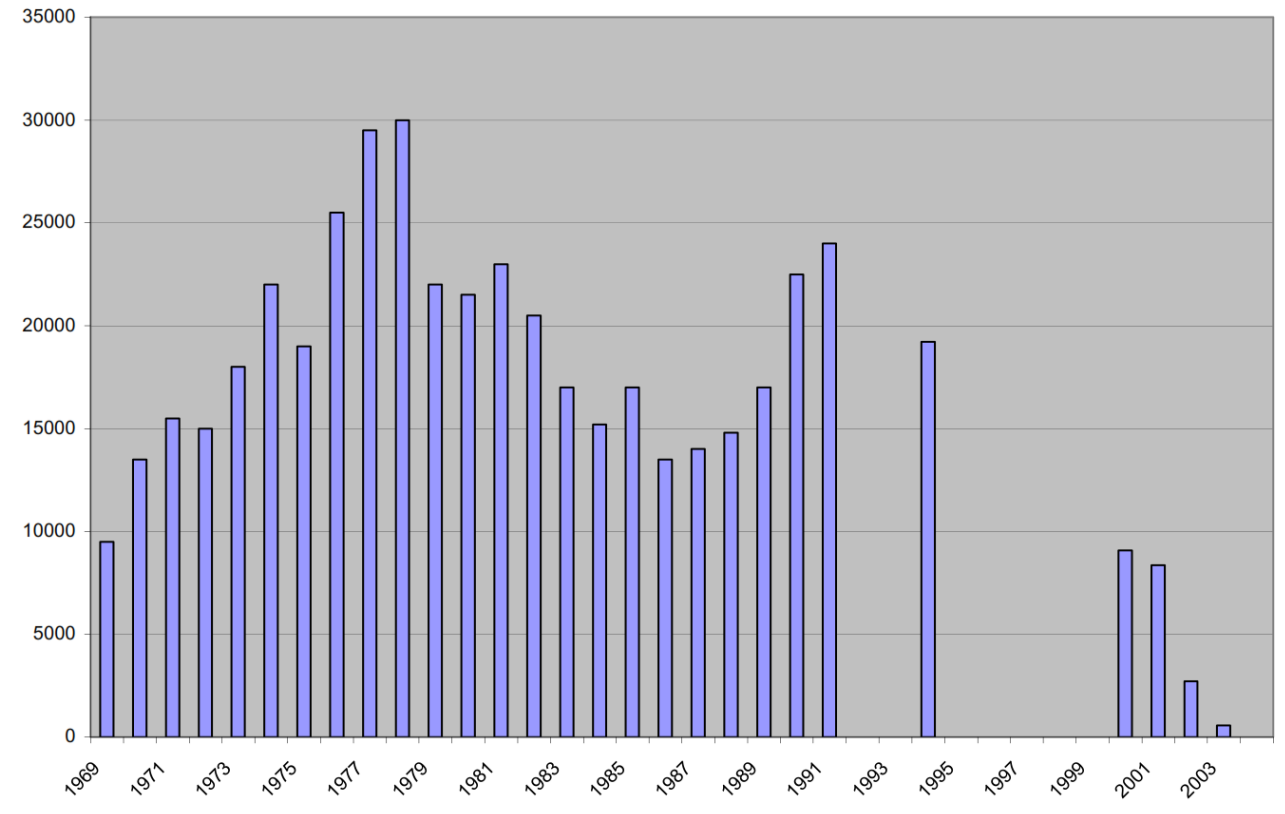

Dalam grafik diatas terdapat tahun-tahun yang data perburuannya tidak ditampilkan. Hal ini bukan berarti tidak ada perburuan di tahun-tahun tersebut, melainkan data perburuan di tahun-tahun tersebut tidak lengkap sehingga tidak ditampilkan. Penyu diburu tidak hanya untuk diambil dagingnya saja, melainkan juga bagian-bagian tubuh yang lain yang mempunyai nilai komersial. Daerah tujuan utama perdagangan dan spesifikasi yang diperdagangkan disajikan dalam tabel berikut (CSTC 1990).

Tabel 4 Daerah tujuan utama perdagangan penyu.

\begin{tabular}{ll}
\hline Daerah Tujuan & Spesifikasi Permintaan \\
\hline Jepang & $\begin{array}{l}\text { Daging, tempurung (shoftshell) untuk dijadikan bekko, serta bagian tubuh } \\
\text { kura-kura yang lain yang dijadikan sebagai assesoris dan hiasan. }\end{array}$ \\
$\begin{array}{l}\text { Wilayah-wilayah } \\
\text { Asia Selatan }\end{array}$ & $\begin{array}{l}\text { Daging, senagian diperuntukkan sebagai pelengkap upacara-upacara } \\
\text { keagamaan }\end{array}$ \\
Cina, Taiwan & Daging, minyak penyu untuk pengobatan tradisional Cina, kilit, dll \\
\hline
\end{tabular}

Jika perburuan ini tidak dihentikan, maka kepunahan populasi penyu tinggal menunggu waktu. Sehingga dalam rangka mencegah kepunahan dan melestarikan populasi kura-kura tetap berada dalam jumlah yang aman harus dilakukan usaha-usaha konservasi.

Dalam makalah ini dilakukan kajian model matematika yang diharapkan dapat memberikan tawaran solusi strategi konservasi populasi penyu.

\section{Model Matematika dan Solusi}

Model matematika dibentuk dalam rangka menjawab masalah strategi konservasi populasi penyu untuk mnyelamatkan dari bahaya kepunahan. Melalui model matematika ini dapat dilihat karakteristik 
pertumbuhan populasi penyu, yang kemudian dapat digunakan untuk menentukan strategi konservasi yang dapat dilakukan. Selanjutnya, dalam rangka menyederhanakan permasalahan yang ada hingga memungkinkan untuk dimodelkan dibuat beberapa asumsi.

\section{Asumsi-Asumsi}

Berikut beberapa asumsi yang digunakan dalam merumuskan model:

1. Populasi penyu hidup pada sebuah teluk dan diasumsikan sebagai daerah tertutup.

2. Populasi ditinjau sejak anak penyu berpindah dari pantai ke laut (kehidupan sesaat anak penyu di pantai tidak diperhitungkan). Hal ini logis, dikarenakan 99\% kehidupan penyu adalah di lautan.

3. Tidak ada predator penyu (setelah penyu berpindah habitat ke laut).

4. Perburuan penyu oleh manusia dilakukan setiap saat dengan jumlah penyu yang diburu adalah $P$ per bulan.

5. Perburuan tidak sampai mengganggu fertilitas penyu.

6. Tidak ada kerusakan lingkungan yang dapat mengurangi populasi penyu.

7. Proporsi antara jumlah populasi jantan dan betina seimbang dan distribusi umur penyu seimbang.

8. Sumber makanan di teluk berlimpah.

9. Satuan waktu yang digunakan adalah bulan.

\section{Kajian Data Penurunan Populasi}

Data penurunan populasi penyu di perairan Canada dan Amerika Utara dari tahun 1980 hingga tahun 2000 dapat digambarkan dalam grafik berikut

Tabel 5 Data penurunan populasi penyu.

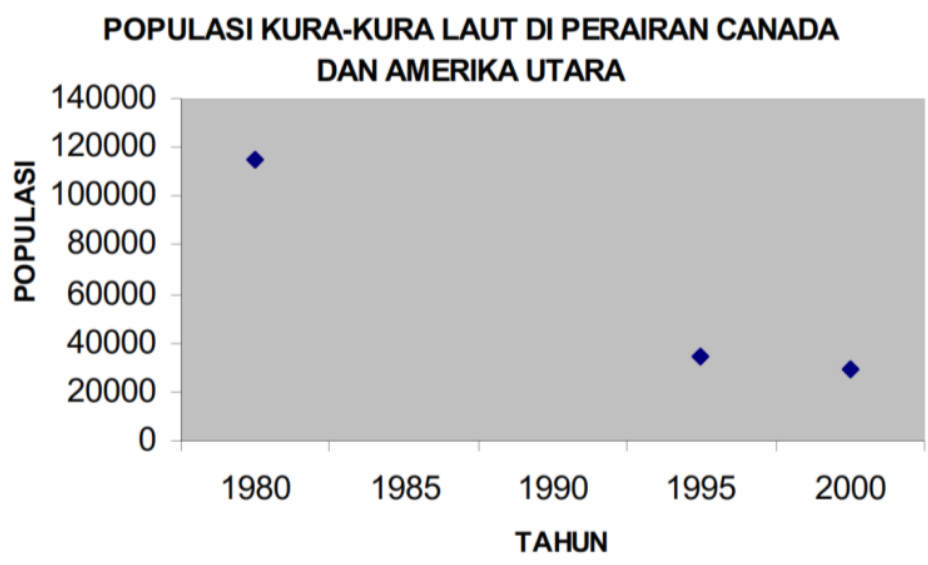

Dari grafik diatas terlihat penurunan yang cukup tajam terjadi pada interval tahun 1980-1995. Pada interval tahun 1995-2000 tetap terjadi penurunan, namun tidak setajam penurunan yang terjadi pada interval tahun sebelumnya. Sebelum merumuskan model untuk menjawab strategi konservasi populasi penyu, terlebih dahulu akan dilakukan pengkajian model yang menggambarkan penurunan populasi penyu pada tahun 1980 hingga 2000.

\section{Model Matematika Tahun 1980-1995}

\section{Dinamika Populasi Penyu}

Penurunan populasi penyu pada tahun 1980-1995 disebabkan oleh perburuan yang terlampau besar dalam rangka memenuhi permintaan perdagangan internasional penyu, sebagaimana tergambar dalam 
Tabel 3. Tabel tersebut menyatakan bahwa jumlah perburuan tidak terlalu fluktuatif, sehingga dapat diambil rata-ratanya perbulan. Selain perburuan, faktor lain yang mempengaruhi dinamika populasi penyu adalah kelahiran alami, kematian alami, serta persaingan antar penyu dalam mendapatkan makanan.

\section{Model Matematika}

Situasi penurunan populasi penyu pada interval tahun 1980-1995 dapat digambarkan dengan model matematika sebagai model logistik dengan perburuan sebagai berikut (Getz dan Haight 1989).

$$
\frac{d K}{d t}=\alpha K\left(1-\frac{K}{c}\right)-P
$$

\section{Notasi:}

$K=$ Jumlah populasi penyu pada bulan $t$

$\alpha=$ rata-rata kelahiran bersih (setelah dikurangi kematian) kura-kura laut per individu per bulan

$C$ = carrying capacity penyu, yaitu jumlah penyu maksimal yang dapat hidup di habitat perairan

$P \quad=$ jumlah penyu yang diburu manusia per bulan

\section{Analisis Dinamika Model}

Tiitk tetap dari model (1) adalah

Dan

$$
K_{1}=\frac{\alpha c+\sqrt{\alpha^{2} c^{2}-4 \alpha P c}}{2 \alpha}
$$

$$
K_{2}=\frac{\alpha c-\sqrt{\alpha^{2} c^{2}-4 \alpha P c}}{2 \alpha}
$$

Untuk memudahkan dalam menganalisa model, model (1) ditulis kembali dalam bentuk

$$
\frac{d K}{d t}=F(K)-H(K)
$$

Dengan

$$
F(K)=\alpha K\left(1-\frac{K}{c}\right)
$$

Menyatakan model logistic murni, dan

$$
H(K)=P
$$

Menyatakan suku perburuan dalam model perburuan (1). 
Phase line dari model (4) dapat digambarkan sebagai berikut.

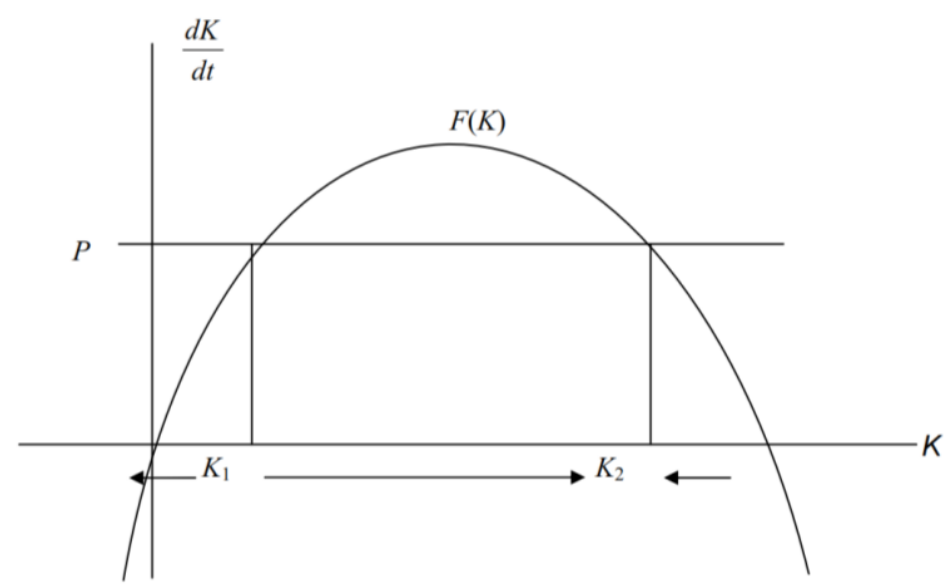

Gambar 2 Phase line model perburuan.

Titik tetap $K_{1}$ dan $K_{2}$ dari model (4) didapat dari perpotongan kurva $F(K)$ dan $H(K)$. Selanjutnya akan ditentukan kestabilan titik tetap $K_{1}$ dan $K_{2}$ sebagai berikut.

1. Untuk $F(K)>H(K)$ maka $\frac{d K}{d t}>0$ sehingga populasi akan meningkat. Dalam phase line dilambangkan dengan anak panah ke kanan sepanjang sumbu $K$.

2. Untuk $F(K)<H(K)$ makan $\frac{d K}{d t}<0$ sehingga populasi akan menurun. Dalam Phase line dilambangkan dengan anak panah ke kiri sepanjang sumbu $K$.

3. Dari analisis kestabilan ini didapat titik tetap $K_{1}$ merupakan titik tetap yang tidak stabil, sedangkan titik tetap $K_{2}$ merupakan titik tetap yang stabil.

\section{Interpretasi Model}

Analisa kestsabilan titik tetap model (1) atau (4) memberikan tiga kemungkinan yang akan terjadi pada populasi penyu

1. Jika pada saat awal $(t=0)$ jumlah populasi penyu berada pada titik 0 dan $K_{1}$ maka populasi akan mengalami penurunan hingga pada suatu saat akan mengalami kepunahan.

2. Jika pada saat awal $(t=0)$ jumlah populasi penyu berada pada titik $K_{1}$ dan $K_{2}$ maka populasi akan mengalami peningkatan hingga akhirnya mendekati titik tetap $K_{2}$.

3. Jika pada saat awal $(t=0)$ jumlah populasi penyu berada di sebelah kanan titik $K_{2}$ maka populasi akan mengalami penurunan hingga akhirnya mendekati titik tetap $K_{2}$.

\section{Estimasi Parameter}

Estimasi parameter diperlukan dalam melakukan validasi model dan menemukan solusi bagi model. Berikut beberapa parameter yang akan diestimasi (Spotila 2004, Lutz et al. 2002 dan Ripple, 1996).

1. Kelahiran bersih $(\alpha)$

a. Kelahiran alami $\left(\alpha_{1}\right)$

Penyu mulai bertelur rata-rata umur 12 tahun, dengan rata-rata usia subur 18 tahun. Ratarata hidup penyu 40 tahun. Setiap tahun rata-rata penyu bertelur sebanyak 6 kali dengan ratarata telur yang dihasilkan adalah 81,5 butir. Dari jumlah ini rata-rata hanya 11 ekor saja yang menetas hingga sampai ke lautan dengan harapan hidup (hingga dewasa) 17.5\%. Diasumsikan proporsi kura-kura jantan dan betina seimbang, dan distribusi umur kura-kura merata. 2 sampai 
3 tahun (rata-rata 2.5 tahun) berturut turut kura-kura bertelur dan setelah itu 1 sampai 2 tahun (rata-rata 1.5 tahun) berturut-turut tidak bertelur.

Dari data dan informasi di atas, dapat diestimasikan kelahiran bersih penyu adalah

$$
\alpha_{1}=\frac{\frac{17,5}{100} \times 11 \times \frac{1}{2} \times \frac{18}{40} \times \frac{2,5}{4}}{12}=0,0222
$$

b. Kematian alami $\left(\alpha_{2}\right)$

Karena rata-rata hidup kura kura laut 40 tahun, maka estimasi kematian alami penyu adalah

$$
\alpha_{2}=\frac{1}{40 \times 12}=0,002083
$$

dari estimasi kelahiran alami dan kematian alami di atas, maka estimasi kelahiran bersih penyu adalah

$$
\alpha=\alpha_{1}-\alpha_{2}=0,0202
$$

2. Carrying capacity $(c)$

Carrying capacity penyu dapat diestimasi dengan memanfaatkan table perhitungan carrying capacity berikut (Bjorndal 2000).

Tabel 6 Carrying capacity penyu.

\begin{tabular}{|c|c|c|c|c|c|c|}
\hline \multirow[b]{3}{*}{$\begin{array}{l}\text { Thalassia productivity } \\
\left(\mathrm{kg} \mathrm{DM} \cdot \mathrm{ha}^{-1} \cdot \mathrm{yr}^{-1}\right)\end{array}$} & \multicolumn{6}{|c|}{$\begin{array}{c}\text { Intake level } \\
\left(\mathrm{kg} \text { DM Thalassia } \cdot(\mathrm{kg} \text { green turtle })^{-1} \cdot \mathrm{yr}^{-1}\right)\end{array}$} \\
\hline & \multicolumn{2}{|r|}{$0.74 \dagger$} & \multicolumn{2}{|r|}{$1.17 \ddagger$} & \multicolumn{2}{|r|}{$1.77 \S$} \\
\hline & $\begin{array}{c}\text { Turtle mas } \\
\text { per area } \\
(\mathrm{kg} / \mathrm{ha})\end{array}$ & $\begin{array}{l}\text { Number of turtles } \\
\text { in Caribbean }\end{array}$ & $\begin{array}{c}\text { Turtle mass } \\
\text { per area } \\
\text { (kg/ha) }\end{array}$ & $\begin{array}{l}\text { Number of turtles } \\
\text { in Caribbean }\end{array}$ & $\begin{array}{c}\text { Turtle mass } \\
\text { per area } \\
(\mathrm{kg} / \mathrm{ha})\end{array}$ & $\begin{array}{l}\text { ss } \\
\text { Number of turtles } \\
\text { in Caribbean }\end{array}$ \\
\hline 216 he & 292 & 38544000 & 185 & 24420000 & 122 & 16104000 \\
\hline 3285 (moderate grazing)\# & 4439 & 585948000 & 2808 & 370656000 & 1856 & 244992000 \\
\hline
\end{tabular}

TABLE 2. Carrying capacities for green turtles on Thalassia testudinum pastures in the Caribbean. Calculations are based on three levels of intake estimated by three different methods and on two levels of $T$. testudinum productivity.

\footnotetext{
Note: DM indicates dry mass.

$\uparrow$ Bjorndal (1982); based on calculation of energy budget for adult female.

¥Bjorndal (1980); based on indigestible lignin ratio and daily feces production.

$\S$ Williams (1988); based on estimates of daily bite counts and bite size.

$\|$ Based on 6600000 ha Thalassia in the Caribbean (Jackson 1997) and turtle size $=50 \mathrm{~kg}$.

I Recalculated from Williams (1988: Table 4).

\# Zieman et al. (1984).
}

Berdasarkan tabel di atas dan berdasarkan luas tumbuhan Thalassia yang menjadi sumber makanan penyu, dalam satu hektar laut mampu menampung $4439 \mathrm{~kg}$ penyu. Jika rata-rata berat penyu adalah $50 \mathrm{~kg} / \mathrm{ekor}$, maka dalam 1 hektar laut mampu menampung 89 ekor penyu. Jika luas perairan adalah sekitar $10.000 \mathrm{~km}^{2}$ dan diasumsikan hanya $1 / 3$ dari luas yang menjadi habitat kura-kura, maka jumlah maksimal penyu yang mampu ditampung dalam area tersebut adalah 296.000 ekor, dibulatkan jadi 300.000 ekor. Sehingga $c=300.000$.

3. Jumlah perburuan $(P)$

Berdasarkan tabel 3 untuk tahun 1980-1995 dapat diambil rata-rata jumlah perburuan penyu per bulan sebesar 1.645 ekor. Jadi $P=1.645$ 


\section{Solusi dan Validasi Model}

Solusi dari model (1) didapat dengan memasukkan nilai estimasi parameter ke dalam model (1) kemudian menyelesaikan persamaan differensial model (1). Model (1) pasca substitusi parameter menjadi

$$
\frac{d K}{d t}=0,0202 K\left(1-\frac{K}{300000}\right)-1645
$$

Solusi model (7) adalah

$$
K(t)=150.000-\frac{115.000}{2.017} \sqrt{6051} \tan \left(\frac{23 \sqrt{6.051} t}{60.000}+\arctan \left(7 \frac{\sqrt{6.051}}{690}\right)\right)
$$

Diperoleh pula titik tetep dari model (7) adalah

$$
K_{1}=123108 \text { dan } K_{2}=193939
$$

Dari Tabel 2, jumlah populasi awal adalah 115000, sehingga populasi awal terletak diantara 0 dan $K_{1}$. dengan demikian populasi penyu akan menurun hingga mengalami kepunahan. Berikut disajikan hasil perhitungan model dengan data yang ada.

Tabel 7 Validasi model (1).

\section{VALIDASI MODEL}

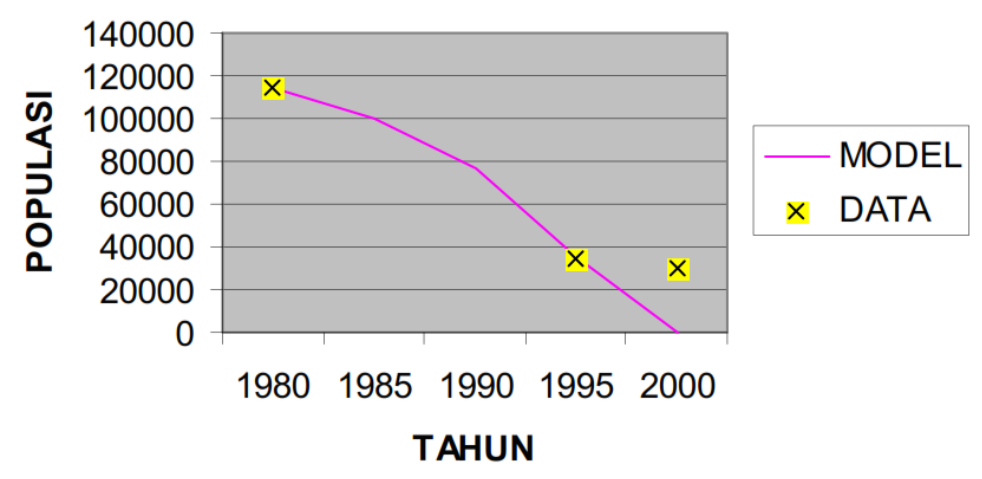

Kesimpulan yang dapat diambil dari model matematika untuk interval tahun 1980-1995 adalah populasi penyu mengalami penurunan yang diakibatkan perburuan yang terlampau besar, yang jika tidak dilakukan upaya penghentian perburuan maka populasi akan mengalami kepunahan.

\section{Model Matematika Tahun 1995-2000}

Dalam tabel 2 Terlihat bahwa pada interval tahun 1995-2000 populasi tetap mengalami penurunan, namun tidak setajam penurunan pada interval tahun sebelumnya. Hal ini dikarenakan pada tahun 1995-2000 pemerintah telah melakukan usaha konservasi, yaitu perlindungan area bertelur penyu yang berpengaruh pada penambahan angka kelahiran dan pengurangan (pembatasan) perburuan. Dua usaha konservasi ini dapat menurunkan penurunan populasi penyu (Spotila 2004, CSTC 1990).

Pola perlindungan area bertelur yang dilakukan dengan cara memetakan area-area bertelur yang memungkinkan untuk diperbaiki dan dilindungi menjadi beberapa zona dan setahap demi setahap melindungi area atau zona tersebut. 


\section{Model Matematika}

Dampak dari perlindungan area bertelur dan pengurangan perburuan yang dilakukan dapat digambarkan dalam model matematika sebagai berikut.

$$
\frac{d K}{d t}=\left[\alpha_{1}(1+s)-\alpha_{2}\right] K\left(1-\frac{K}{c}\right)-P
$$

Notasi:

$K=$ jumlah populasi penyu pada bulan $t$

$\alpha_{1}=$ rata-rata kelahiran alami kura-kura laut per individu per bulan

$\alpha_{2}=$ rata-rata kematian alami penyu per individu per bulan

$s=$ Proporsi area bertelur yang sekarang dilindungi terhadap area bertelur sebelumnya

$c$ = carrying capacity penyu, yaitu jumlah penyu maksimal yang dapat hidup di habitat perairan

$P \quad=$ jumlah penyu yang diburu manusia per bulan

\section{Estimasi Parameter}

1. Proporsi perlindungan area bertelur (s)

Berikut adalah data perlindungan area bertelur yang dilakukan pada tahun 1995-2000 (Martin dan James 2005, CSTN 1996)

Tabel 8 Data perlindungan area bertelur.

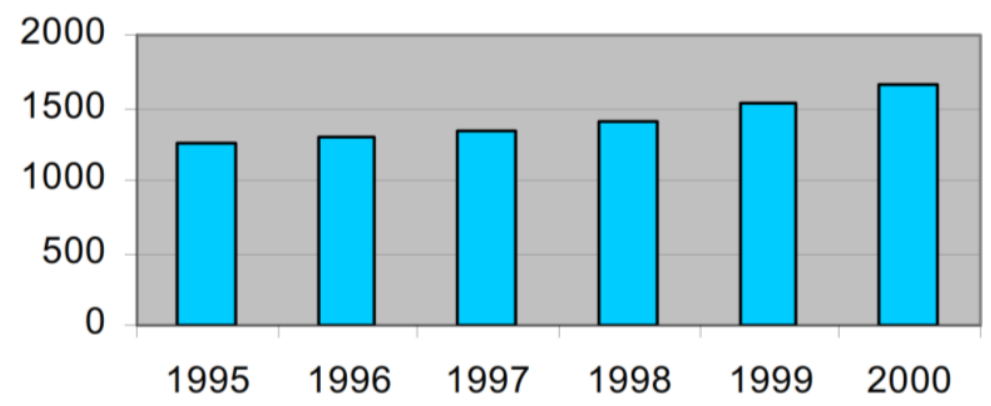

Berdasarkan Tabel 8 di atas, didapat rata-rata perlindungan area bertelur yang dilakukan adalah $14.12 \%$ pertahun dari area bertelur sebelumnya. Sehingga didapat $s=0.412$.

2. Perburuan $(P)$

Berdasarkan Tabel 3. untuk tahun 19952000 dapat diambil rata-rata jumlah perburuan penyu per bulan sebesar 750 ekor. Jadi $P=750$.

\section{Analisa Dinamika dan Interpretasi Model}

Model (9) tetap masih berupa model logistik dengan perburuan sebagaimana model (1). Sehingga analisa dan interpretasi model (9) sama dengan analisa dan interpretasi model (1).

\section{Solusi dan Validasi Model}

Dengan memasukkan nilai parameter yang telah diestimasi ke dalam model (9), didapat 


$$
\frac{d K}{d t}=0.0230 K\left(1-\frac{K}{300000}\right)-750
$$

Solusi model (10) adalah

$$
K(t)=150000-\frac{50000}{79} \sqrt{7031} \tan \left(\frac{\sqrt{7031} t}{200000}+\arctan \left(\frac{231 \sqrt{7031}}{8900}\right)\right)
$$

Diperoleh pula titik tetap dari model (10) adalah

$$
K_{1}=37130 \text { dan } K_{2}=262869
$$

Dari Tabel 2, jumlah populasi awal adalah 115000, sehingga populasi awal terletak diantara 0 dan $K_{1}$. Dengan demikian populasi penyu akan menurun hingga mengalami kepunahan. Berikut disajikan hasil perhitungan model dengan data yang ada.

Tabel 9 Validasi model (9).

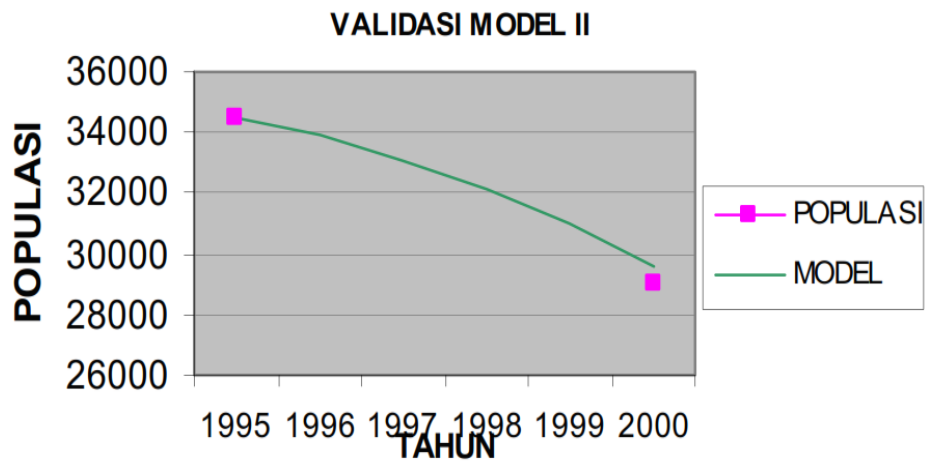

Kesimpulan yang dapat diambil dari model matematika untuk interval tahun 1995-2000 adalah meskipun telah dikalukan perlindungan area bertelur dan pengurangan perburuan, populasi penyu tetap mengalami penurunan meskipun tidak sebanyak interval tahun sebelumnya. Sehingga diperlukan strategi konservasi yang lebih baik guna meningkatkan dan menjaga kelestarian populasi penyu.

\section{Model Matematika Untuk Menjawab Masalah}

Berdasarkan pengkajian data penurunan populasi penyu di perairan Canada dan Amerika Utara diatas, pada bagian ini akan dirumuskan model matematika untuk menjawab strategi konservasi penyu guna menyelamatkan dari kepunahan. Model matematika dibentuk berdasarkan karakteristik hidup penyu. Strategi konservasi yang ditawarkan adalah pembatasan perburuan dan pelepasan anak kura-kura dari penangkaran ke laut.

\section{Dinamika Populasi Penyu}

Populasi penyu dapat dibagi menjadi beberapa sub populasi sebagaimana terdapat dalam tabel 1 . Dalam model matematika yang akan dibentuk, populasi penyu dibagi menjadi dua sub populasi yaitu penyu kecil $\left(K_{K}\right)$ dan penyu dewasa $\left(K_{D}\right)$. Hal ini didasarkan pada fakta bahwa penyu mulai diburu pada sub populasi Large Juvenile.

Faktor-faktor yang mempengaruhi pertumbuhan sub populasi kura-kura kecil adalah (Spotila 2004):

1. Bertambah karena: kelahiran alami, pelepasan dari penangkaran

2. Berkurang karena: kematian alami, kura-kura kecil yang menjadi dewasa, persaingan dalam mendapatkan makanan 
Faktor-faktor yang mempengaruhi pertumbuhan sub populasi kura-kura dewasa adalah:

1. Bertambah karena: kura-kura kecil yang menjadi kura-kura dewasa

2. Berkurang karena: kematian alami, perburuan, persaingan dalam mendapatkan makanan

Beberapa asumsi yang digunakan untuk menyusun model adalah:

1. Distribusi umur populasi penyu merata.

2. Sub populasi penyu kecil dan dewasa hidup dalam habitat yang sama dan mempunyai carrying capacity yang sama pula.

3. Perburuan yang diperbolehkan adalah konstan per bulan.

\section{Model Matematika}

Berdasarkan faktor yang mempengaruhi pertumbuhan poulasi penyu dan asumsi-asumsi diatas, model matematika dirumuskan sebagai berikut

$$
\begin{gathered}
\frac{d K_{K}}{d t}=\alpha_{1} K_{D}-\alpha_{2} K_{K}+Q-\gamma K_{K}-\delta_{1} K_{K}\left(K_{K}+K_{D}\right) \\
\frac{d K_{D}}{d t}=\gamma K_{K}-\alpha_{3} K_{D}-P-\delta_{2} K_{K}\left(K_{K}+K_{D}\right)
\end{gathered}
$$

Notasi;

$K_{K}=$ jumlah sub populasi penyu kecil pada bulan $t$

$K_{D}=$ jumlah sub populasi penyu dewasa pada bulan $t$

$\alpha_{1}=$ rata-rata kelahiran alami penyu dewasa per individu per bulan

$\alpha_{2}=$ rata-rata kematian alami penyu kecil per individu per bulan

$\alpha_{3}=$ rata-rata kematian alami penyu dewasa per individu per bulan

$c$ = carrying capacity penyu, yaitu jumlah penyu maksimal yang dapat hidup di habitat perairan

$\gamma=$ Proporsi penyu kecil yang menjadi dewasa per bulan

$Q=$ Jumlah penyu kecil yang dilepas dari penangkaran per bulan

$P \quad=$ jumlah penyu dewasa yang diburu manusia per bulan

$\delta_{1}=$ proporsi penurunan penyu kecil karena adanya persaingan dalam mendapatkan makanan antar kura-kura kecil maupun dewasa

$\delta_{2}=$ proporsi penurunan penyu dewasa karena adanya persaingan dalam mendapatkan makanan antar kura-kura kecil maupun dewasa

Variabel-variabel di atas memenuhi $0<\alpha_{1}, \alpha_{2}, \alpha_{3}, \delta_{1}, \delta_{2}, \gamma<1$ dan asumsikan $\alpha_{1}<\alpha_{2}<\alpha_{3}$, $\delta_{1}<$ $\delta_{2}$, dan $Q>P$.

\section{Analisa Dinamika Model}

Menggunakan bantuan software Maple, didapat titik tetap dari model (12) adalah

$$
\left\{K_{K}=\frac{\alpha_{3} H+P+\delta_{2} H^{2}}{\gamma-\delta_{2} H}, K_{D}=H\right\}
$$

$H=$ akar dari $\left(\alpha_{1} \delta_{2}^{2}+\alpha_{2} \delta_{2}^{2}-\delta_{1} \alpha_{3} \delta_{2}+\gamma \delta_{2}^{2}-\delta_{1} \gamma \delta_{2}\right) Z^{3}$. Dengan 


$$
\begin{aligned}
& \left(-2 \gamma \delta_{2} \alpha_{1}+\alpha_{2} \alpha_{3} \delta_{2}-\gamma \delta_{2} \alpha_{2}-\gamma^{2} \delta_{2}-\gamma \delta_{1} \alpha_{3}+\gamma \delta_{2} \alpha_{3}-\delta_{1} \delta_{2} P+\delta_{2}^{2}\right) Z^{2} \\
& \left(\gamma \delta_{1} P-2 Q \gamma \delta_{2}-2 \delta_{1} \alpha_{3} P+\alpha_{2} \delta_{2} P-\gamma^{2} \alpha_{3}+\gamma \delta_{2} P+\gamma^{2} \alpha_{3}\right) Z \\
& \left(-\gamma \alpha_{2} P-\delta_{1} P^{2}+\gamma^{2} Q-\gamma^{2} P\right) .
\end{aligned}
$$

Karena bahasan dalam model ini adalah populasi makhluk hidup maka titik tetap model (12) akan eksis jika bernilai real positif. Dengan menggunakan kriteria Descartes (Jones dan Bedient 1998), akan ditentukan eksistensi dari $H$ sebagai berikut.

- Koefisien pangkat 3 dari $H$ adalah:

$$
\alpha_{1} \delta_{2}^{2}+\alpha_{2} \delta_{2}^{2}-\delta_{1} \alpha_{3} \delta_{2}+\gamma \delta_{2}^{2}-\delta_{1} \gamma \delta_{2} \text { atau }\left(\alpha_{1}+\alpha_{2}+\gamma\right) \delta_{2}^{2}-\left(\alpha_{3}+\gamma\right) \delta_{1} \delta_{2}
$$

Karena $\alpha_{1}+\alpha_{2}>\alpha_{3}$ dan $\delta_{2}>\delta_{1}$ maka $\alpha_{1}+\alpha_{2}+\gamma>\alpha_{3}+\gamma$, sehingga $\left(\alpha_{1}+\alpha_{2}+\gamma\right) \delta_{2}^{2}-$ $\left(\alpha_{3}+\gamma\right) \delta_{1} \delta_{2}>0$. Dengan demikian didapat koefisien pangkat $3>0$.

- Koefisien pangkat 2 dari $H$ adalah:

$$
-2 \gamma \delta_{2} \alpha_{1}+\alpha_{2} \alpha_{3} \delta_{2}-\gamma \delta_{2} \alpha_{2}-\gamma^{2} \delta_{2}-\gamma \delta_{1} \alpha_{3}+\gamma \delta_{2} \alpha_{3}-\delta_{1} \delta_{2} P+\delta_{2}^{2}
$$

Karena $\alpha_{1}>\alpha_{2}>\alpha_{3}$ maka $2 \gamma \alpha_{1}>\alpha_{2} \alpha_{3}$ sehingga $-2 \gamma \alpha_{1}+\alpha_{2} \alpha_{3}<0$,

karena $\alpha_{2}>\alpha_{3}$ maka $\alpha_{2}+\gamma>\alpha_{3}$ sehingga $\gamma \alpha_{2}-\gamma^{2}-\alpha_{3}+\gamma \alpha_{3}<0$, dan

karena $Q>P$ dan $\delta_{1}<\delta_{2}$ maka $-\delta_{1} P+\delta_{2} Q>0$.

Sehingga koefisien pangkat 2 dari $H$ lebih kecil dari nol (negatif).

- Koefisien pangkat 1 dari $H$ adalah:

$$
\gamma \delta_{1} P-\delta_{1} \alpha_{3} P+\alpha_{2}-\gamma^{2} \alpha_{3}+\gamma \delta_{2} P+\gamma^{2} \alpha_{3}
$$

Karena $2 Q \delta_{2}>\delta_{2} P$ maka $2 Q \delta_{2}+\delta_{2} P<0$ dan

Karena $\delta_{1} P+\alpha_{3}+\alpha_{2} \alpha_{3}>\alpha_{1} \gamma$ maka $-\delta_{1} P-\alpha_{3}-\alpha_{2} \alpha_{3}+\alpha_{1} \gamma<0$.

Agar koefisien pangkat 1 bernilai negatif, maka $2 \delta_{1} \alpha_{3}<\delta_{2} \alpha_{2}$. Sehingga didapatkan syarat eksistensi $2 \delta_{1} \alpha_{3}<\delta_{2} \alpha_{2}$.

- Koefisien pangkat 0 dari $H$ adalah:

$$
-\gamma \alpha_{2} P-\delta_{1} P^{2}+\gamma^{2} Q-\gamma^{2} P
$$

Karena $\gamma \alpha_{2} P+\delta_{1} P^{2}+\gamma^{2} P>\gamma^{2} Q$ maka koefisien pangkat $0<0$.

Dari tanda-tanda koefisien pangkat di atas, didapat jumlah variasi tanda adalah 1 , sehingga $v=1$.

Oleh karena itu bilangan yang $N$ dirumuskan dengan $0 \leq N \leq \frac{1}{2}$, dipenuhi oleh $N=1$. Sehingga menurut kriteria Descartes, persamaan karakterisrik (15) hanya memiliki satu akar real positif. Dengan demikian maka titik tetap model (12) eksis, dengan syarat eksistensi $2 \delta_{1} \alpha_{3}<\delta_{2} \alpha_{2}$ atau $\delta_{1}<\frac{\delta_{2} \alpha_{2}}{2 \alpha_{3}}$.

Setelah dapat ditentukan syarat eksistensi titik tetap model (12), selanjutnya akan ditentukan syarat kestabilan titik tetap model (12) sebagai berikut. 
Matriks Jacobian dari model (12) adalah:

$$
\left[\begin{array}{cc}
-\alpha_{2}-\gamma-\delta_{1}\left(K_{k}+T_{d}\right)-\delta_{1} K_{k} & \alpha_{1}-\delta_{1} K_{k} \\
\gamma-\delta_{2} H & -\alpha_{3}-\delta_{2}\left(K_{k}+T_{d}\right)-\delta_{2} T_{d}
\end{array}\right]
$$

Substitusikan titik tetap (14) ke matriks Jacobian (16) diperoleh matriks

$$
\left[\begin{array}{cc}
-\alpha_{2}-\gamma-\delta_{1}\left(\frac{\alpha_{3} H+P+\delta_{2} H^{2}}{-\gamma+\delta_{2} H}+H\right)+\frac{\delta_{1}\left(\alpha_{3} H+P+\delta_{2} H^{2}\right)}{-\gamma+\delta_{2} H} & \alpha_{1}-\delta_{1} \frac{\delta_{1}\left(\alpha_{3} H+P+\delta_{2} H^{2}\right)}{-\gamma+\delta_{2} H} \\
-\gamma+\delta_{2} T_{d} & -\alpha_{3}-\delta_{2}\left(\frac{\left(\alpha_{3} H+P+\delta_{2} H^{2}\right)}{-\gamma+\delta_{2} H}\right)-\delta_{2} H
\end{array}\right]
$$

Polynomial karakteristik dari matriks (17) diatas adalah:

$$
\begin{gathered}
\left(-\lambda \delta_{2}^{2} H P+\alpha_{2} \delta_{2}^{2} H^{2} \lambda-\alpha_{2} \delta_{2}^{2} H P-\delta_{1} \alpha_{3} H^{3} \delta_{2}^{2}-\delta_{1} \delta_{2}^{2} H^{3} \lambda-2 \alpha_{2} \gamma \lambda \delta_{2} H\right. \\
+\lambda^{2} \delta_{2}^{2} H^{2}+\lambda \delta_{2}^{3} H^{3}+\alpha_{2} \delta_{2}^{3} H^{3}+2 \delta_{1} P^{2} \delta_{2}+\alpha_{1} \delta_{2}^{3} H^{3}+\alpha_{2} \gamma^{2} \alpha_{3}+\gamma^{2} P \delta_{2} \\
+2 \gamma^{2} \delta_{2} H-3 \gamma^{2} \delta_{2}^{2} H^{2}+\gamma \delta_{2}^{3} H^{3}+\delta_{1} P \gamma^{2}+\gamma^{2} \lambda^{2}+\gamma^{3} \alpha_{3}-\alpha_{1} \gamma^{3} \\
-2 \delta_{1} \alpha_{3} H^{2} \lambda \delta_{2}+2 \delta_{1} \alpha_{3} H P \delta_{2}-2 \delta_{1} P \lambda \delta_{2} H+3 \delta_{1} P \gamma \delta_{2} H-\lambda \delta_{2} H \gamma \alpha_{3} \\
-2 \gamma \lambda^{2} \delta_{2} H+\gamma \lambda P \delta_{2}-2 \gamma \lambda \delta_{2}^{2} H^{2}+\alpha_{2} \gamma P \delta_{2}+2 \alpha_{2} \gamma^{2} \delta_{2} H-3 \alpha_{2} \gamma \delta_{2}^{2} H^{2} \\
-\gamma^{2} \delta_{2} H \alpha_{3}-\gamma \delta_{2}^{2} H P+2 \delta_{1} \alpha_{3}^{2} H \gamma+2 \delta_{1} P \gamma \lambda+2 \delta_{1} P \gamma \alpha_{3}+\delta_{1} H \gamma^{2} \lambda \\
+2 \delta_{1} H \gamma^{2} \alpha_{3}+3 \delta_{1} H^{2} \gamma^{2} \delta_{2}-\delta_{1} H^{3} \gamma \delta_{2}^{2}+3 \alpha_{1} \gamma^{2} \delta_{2} H-3 \alpha_{1} \gamma \delta_{2}^{2} H^{2}+\alpha_{2} \gamma^{2} \lambda \\
\left.+\gamma^{2} \lambda \alpha_{3}-\alpha_{2} \delta_{2} H \gamma \alpha_{3}+3 \delta_{1} \alpha_{3} H^{2} \gamma \delta_{2}+\gamma^{3} \lambda+2 \delta_{1} \alpha_{3} H \gamma \lambda\right) /\left(-\gamma+\delta_{2} H\right)^{2}
\end{gathered}
$$

Berdasarkan kriteria kestabilan Hurwitz (Chen 1984), didapat syarat kestabilan titik tetap (14) adalah

$$
\begin{aligned}
& -\alpha_{2} \delta_{2}^{2} H P-\alpha_{3} \delta_{1} H^{3} \delta_{1}^{2}+\alpha_{2} \delta_{2}^{3} H^{3}+2 \delta_{1} P^{2} \delta_{2}+\alpha_{1} \delta_{2}^{3} H^{3}+\alpha_{2} \gamma \alpha_{3} \\
& +\gamma^{2} P \delta_{2}-3 \gamma^{2} H^{2} \delta_{2}^{2}+\gamma H^{3} \delta_{2}^{3}+\gamma^{2} P \delta_{1}+\gamma^{3} \alpha_{3}-\gamma^{3} \alpha_{1}+2 \alpha_{3} \delta_{2} H P \\
& +3 \alpha_{3} \delta_{1} \gamma \delta_{2} H P+\gamma P \delta_{2} \alpha_{2}+2 \gamma P \delta_{2} \alpha_{2}-3 \gamma P \delta_{2}^{2} H^{2} \alpha_{2}-\gamma^{2} \delta_{2} H^{2} \alpha_{3} \\
& \gamma P \delta_{2}^{2} H^{2}+2 \gamma \delta_{1} H \alpha_{3}^{2}+2 \gamma \delta_{1} P \alpha_{3}+2 \gamma^{2} \delta_{1} H \alpha_{3}+3 \gamma \delta_{1} H^{2} \\
& -\gamma \delta_{1} H^{3} \delta_{2}^{2}+3 \gamma^{2} \delta_{2} H \alpha_{1}-3 \gamma \delta_{2}^{2} H^{2}>0
\end{aligned}
$$

dan

$$
\begin{aligned}
& \alpha_{2} \gamma^{2}+\alpha_{3} \gamma^{3}+\gamma \delta_{2} P+\gamma^{2} \delta_{1} H+H^{2} \delta_{2}^{2} \alpha_{2}+2 H \gamma \delta_{1} \alpha_{3}+2 \gamma \delta_{1} P \\
& -2 H \delta_{1} P \delta_{2}+H^{2} \delta_{2}^{3}-2 \alpha_{2} \gamma \delta_{2} H-\delta_{2}^{2} H P-2 \alpha_{3} \gamma \delta_{2} H^{2} \delta_{1} \\
& -2 \gamma \delta_{2}^{2} H+\gamma^{3}-\delta^{2}{ }_{2} H^{3} \delta_{1}-\alpha_{3} \gamma \delta_{2} H>0
\end{aligned}
$$




\section{Interpretasi Model}

Analisa model memberikan interpretasi bahwa agar populasi tetap eksis maka beberapa hal berikut harus dipenuhi:

1. Angka kelahiran penyu dewasa harus lebih besar dari angka kematian alami penyu kecil.

2. Angka kematian alami penyu kecil harus lebih besar dari angka kematian alami penyu dewasa.

3. Jumlah penyu yang dilepas dari penangkaran harus lebih besar dari jumlah penyu yang diperbolehkan untuk diburu.

4. Angka persaingan penyu kecil dalam mendapatkan makanan harus lebih kecil dibandingkan angka persaingan penyu dewasa dan memenuhi pertidaksamaan

$$
\delta_{1}<\frac{\delta_{2} \alpha_{2}}{2 \alpha_{3}}
$$

\section{Kesimpulan dan Saran}

Kajian model matematika tentang strategi konservasi populasi penyu memberikan penawaran solusi bahwa dalam rangka menyelamatkan populasi dari kepunahan maka dapat dilakukan dua bentuk konservasi yaitu:

1. Menangkarkan penyu kemudian secara periodic melepaskan penyu tersebut dari penangkarannya.

2. Membatasi perburuan penyu.

Kajian model diatas masih sangat sederhana dan baru dapat memberikan solusi serta saran yang masih sangat umum. Kesederhanaan pengkajian model ini memberikan peluang kepada semua pihak yang tertarik pada bidang permodelan untuk melakukan pengkajian lebih jauh tentang srtategi konservasi populasi penyu. Sehingga solusi yang ditawarkan akan sangat bermanfaat bagi pihak-phak yang berkonsentrasi pada upaya konservasi populasi ini.

\section{Referensi}

[1] Bjorndal, K. A., Bolten, A. B., dan Chaloupka, M. Y., Green Turtle Somatic Growth Model: Evidence Fordensity Dependence, Ecological Applications, vol. 10 no 1, 269282, 2000.

[2] Bjorndal, K. A. dan Bolten, A. B., From Ghosts to Key Species: Restoring Sea Turtle Populations to Fulfill their Ecological Roles, Marine Turtle Newsletter, vol. 100, 16-21, 2003.

[3] Canadian Sea Turtles Network (CSTN), http://canadaseaturtle.wordpress.com/, diakses tanggal 12 April 2006.

[4] Chen, C-T, Linear System Theory and Design, CBS Collegde Publising, Japan, 1984.

[5] Committee on Sea Turtles Conservation (CSTC), Decline of the Sea Turtles: Causes and Preventions, National Academy Press, Washington DC, 1990.

[6] Getz, W. M. dan Haight, R. G., Population Harvesting: Demographic Model of Fish, Forest, and Animal Resources, Princeton University Press, 1989.

[7] Jones, P. S. dan Bedient, J. D., The historical roots of elementary mathematics. Dover Courier Publications, 1998.

[8] Lutz, P. L., Musicj, J. A. dan Wyneken, J., The Biology of Sea Turtles, Volume II, CRC Press, 2002.

[9] Martin, K. dan James, M. C., Conserving Sea Turtles in Canada: Successful Community-Based Collaboration Between Fishers and Scientists, Chelonian Conservation and Biology, vol. 4 no. 4, 889907, 2005.

[10] Pritchard, P. C. H., dan Stubbs, T. H., An Evaluation of Sea Turtle Populations and Survival Status on Vieques Island, Final report submitted to Department of the Navy, Naval Ocean Centre, San Diego, 1982.

[11] Ripple, J. Sea Turtles of the Wolrd, Voyageur Press, 1996.

[12] Spotila, J. R., Sea Turtlrs: A Complete Guide to Their Biology, Behaviour, and Conservation, Johns Hopkins University Press, 2004 